\title{
Association between periodontitis and the development of systemic diseases
}

Kimihiro Igari ${ }^{1 *}$, Toshifumi Kudo ${ }^{1}$, Takahiro Toyofuku' ${ }^{1}$, Yoshinori Inoue ${ }^{1}$ and Takehisa Iwai ${ }^{2}$

*Correspondence: igari.srg1@tmd.ac.jp (1) CrossMark

'Division of Vascular and Endovascular Surgery, Department of Surgery, Tokyo Medical and Dental University, Tokyo, Japan.

${ }^{2}$ Tsukuba Vascular Center and Buerger Disease Research Institute, Ibaraki, Japan.

\begin{abstract}
Periodontal diseases, common infectious diseases seen in humans, are characterized by gingival inflammation and a loss of connective tissue and bone around the roots of teeth, which leads to eventual tooth exfoliation. In the past decade, the association between periodontal diseases and the development of systemic diseases has received increasing attention. Periodontal pathogens and their products, as well as inflammatory mediators produced in periodontal tissues, can enter the bloodstream, thereby causing and/ or contributing to the development of systemic diseases. A variety of recent studies have compiled various results showing that periodontal infections are implicated in the development of various systemic diseases. This review summarizes the evolution of the focal infection theory to the current understanding of the pathophysiology of periodontal disease and presents an update of the mechanisms and relationships between chronic periodontitis and systemic diseases, including cardiovascular diseases, respiratory infections, preterm delivery of low-birth-weight fetuses and diabetes mellitus.
\end{abstract}

Keywords: Periodontitis, cardiovascular disease, diabetes mellitus, pulmonary disease

\section{Introduction}

Understanding the etiology and pathogenesis of periodontal diseases and their chronic, inflammatory and infectious nature necessitates recognizing the possibility that these infections may have effects somewhere in the body.

The concept that oral diseases and systemic diseases influence each other goes back to the theory of focal infection. In 1891, Miller [1] published his theory regarding focal infection in which he indicated that microorganisms and their products are able to access parts of the body that are adjacent to or distant from the mouth. The proponents of this concept assume that microorganisms present in dental plaque and their metabolic products may enter the bloodstream, thereby causing many systemic diseases and sometimes resulting in degenerative conditions. Further studies including epidemiological and statistical analyses have been conducted. In addition, molecular and genetic research is proceeding.

In recent years, the concept of focal infection has changed and now mostly relies on the correlation between chronic periodontitis and systemic diseases. Offenbacher [2] introduced the concept of 'periodontal medicine' as a discipline focusing on validating this relationship and its biological plausibility using human and animal studies. The American Academy of Periodontology launched an effort to educate the public about new discoveries, namely, that infections in the mouth may play an important role in disorders involving other parts of the body [3]. At present, it is generally known that a patient's oral status is connected with their systemic health, as poor oral health may cause serious underlying diseases concomitantly and may predispose patients to developing other systemic diseases [4]. Dental and medical researchers and clinicians have resumed studying the relationship between oral diseases and systemic conditions with a more scientific approach.

This review provides an overview of the relationship between periodontitis and systemic diseases, including cardiovascular diseases, adverse pregnancy outcomes, diabetes mellitus and respiratory diseases.

\section{Review}

\section{Search strategy and selection criteria}

Data for this Review were identified by searches of MEDLINE, Current Contents, PubMed, and references from relevant articles using the search terms "periodontitis", "periodontal disease", and "systemic disease". Abstracts and reports from meetings were included only when they related directly to previously published work. Only articles published in English between 1980 and 2013 were included.

\section{Periodontitis}

Periodontal disease comprises a group of bacterial inflammatory diseases of the supporting tissues of the teeth (gingiva, periodontal ligament, cementum and alveolar bone). In 1999, a newer classification of periodontal diseases was proposed by the American Academy of Periodontology [5]. Briefly, 
Igari et al. Oral Biology and Dentistry 2014,

gingivitis is inflammation of the gingiva around the teeth that does not cause a loss of periodontal attachment. Otherwise, periodontitis is characterized by periodontal ligament detachment from the cementum with consequent formation of periodontal pockets, alveolar bone resorption, gingival recession, tooth migration, diastema formation between teeth, tooth mobility, abscess formation and tooth loss.

Gingivitis is manifested by red, swollen gums and bleeding that may occur with tooth brushing and can advance to periodontitis if left untreated. Over time, the plaque biofilm can spread and grow below the gum line (subgingival area), and toxins produced by bacteria in the plaque biofilm can irritate the gums. These toxins stimulate a chronic inflammatory response in which the body, in essence, turns on itself, and supporting tissues and bone are broken down and destroyed. In this process, gums separate from the teeth, forming infectious periodontal pockets (spaces between the teeth and gums). Gingivitis is reversible, although if left untreated, it can progress to periodontitis [6]. As the disease progresses, the pockets become deeper and more gum tissue and bone are destroyed. Often, this destructive process is asymptomatic, although teeth can eventually become loose and may need to be removed.

Periodontal diseases have been proposed to affect at least one tooth in $80 \%$ of adults worldwide [7]. The primary cause has been shown to be bacterial plaque, a sticky, colorless film that is constantly formed on teeth. The widely known periodontal pathogens present in plaque are as follows: Porphyromonas gingivalis (P. gingivalis), Prevotella intermedia (P. intermedia), Treponema denticola (T. denticola), Tannerella forsythia (T. forsythia), Campylobacter rectus (C. rectus), Selenomonas spp., Agregatibacter actinomycetemcomitans ( $A$. actinomycetemcomitans), Eubacterium timidum, Fusobacterium nucleatum (F. nucleatum) and Parvimonas micra [8].

\section{Mechanisms of periodontal infection and systemic diseases}

In oral cavities, the innate host defense system is thought to act toward limiting the spread of oral bacteria by maintaining an intact gingival epithelium as an innate physical barrier. The epithelium is also important for orchestrating host inflammatory responses [9]. However, as the disease progresses, the epithelium becomes ulcerated, exposing the underlying connective tissues and blood capillaries to the plaque biofilm. Exposed ulcerative areas facilitate the direct entry of bacteria into the circulation during eating and tooth brushing. This mechanism is thought to be the primary cause of periodontitis-related systemic diseases. Once periodontal pathogens and their toxins such as cytolytic enzymes and lipopolysaccharide (LPS) have access to the bloodstream, a number of inflammatory mediators, including tumor necrosis factor-alpha (TNF-a), interleukin (IL)-1 $\beta$, prostaglandin $E_{2}$ $\left(\mathrm{PGE}_{2}\right)$ and $\gamma$-interferon ( $\gamma$-IFN), are produced. These mediators can enter the bloodstream and contribute to the global inflammatory burden [10]. Therefore, systemic exposure to periodontal pathogens and toxins and periodontal-derived/ elicited inflammatory mediators may determine the pathologic consequences in different organs.

The mechanisms by which periodontal infections may influence systemic health have been described as follows:

1. Oral-hematogenous spread of periodontal pathogens and direct effects to target organs.

2. Transtracheal spread of periodontal pathogens and direct effects to target organs.

3. Oral-hematogenous spread of cytokines and antibodies with effects at distant organs.

Epidemiological and interventional studies have revealed close associations between periodontal diseases and systemic diseases such as cardiovascular diseases (CVDs) [11-13], aspiration pneumonia [14], preterm delivery of low-birthweight fetuses $[15,16]$, diabetes mellitus $[17,18]$ and so on This review discusses which mechanisms contribute to each disease.

\section{Oral-hematogenous spread of periodontal pathogens and direct effects to target organs}

The first mechanism, oral-hematogenous spread of periodontal pathogens and direct effects to target organs is characterized by metastatic injury or infection caused by translocation of bacteria, microbial toxins and inflammatory mediators. These diseases include CVD, ischemic heart disease, Buerger disease and peripheral arterial disease caused by atherosclerosis $[19,20]$.

CVD is a group of heart and vascular diseases, including high blood pressure, congestive heart failure and myocardial infarction [21]. Atherosclerosis is the primary cause of all CVDs [22]. Since a significant epidemiological relationship has been described, etiological investigations have been performed to determine whether oral infections are a risk factor or a direct cause of CVDs. In the past decade, a meta-analysis revealed that periodontal diseases are associated with future coronary heart diseases, which are increased in individuals older than 65 years of age $[23,24]$.

Bacterial DNAs of periodontal pathogens such as $P$. gingivalis, T. forsythensis, T. denticola, A. actinomycetemcomitans and C. rectus have been detected in stenotic coronary artery plaque samples [13] and in aneurysm walls and aneurysmal thrombus tissues $[\mathbf{1 2}, \mathbf{2 5}]$. Periodontal bacteria are not detectable using standard culture techniques and are extremely difficult to identify [26]. When the bacteria are not expected to live in the vessel thrombi or plaques, methods for identification are extremely limited. Therefore, the established polymerase chain reaction (PCR) method is used to detect the DNAs of oral bacteria $[\mathbf{2 7}, \mathbf{2 8}]$. After the presence of bacteria is confirmed, immunofluorescence methods are useful for locating the bacteria in vessel walls [29].

Several studies regarding the direct relationship between chronic periodontitis and CVDs provide evidence that chronic periodontitis increases the level of systemic 
inflammation as measured by the levels of C-reactive protein (CRP) and other biomarkers [30]. Additional potential mechanisms have become clear: continuous and lasting exposure to bacteria of the oral cavity or bacterial toxins may initiate pathological changes in blood vessel walls and therefore act as a precursor of atherosclerosis in susceptible hosts. In this context, there are sufficient data to consider that $P$. gingivalis, A. actinomycetemcomitans and $P$. intermedia have the ability to invade host cells, including the epithelium and endothelium, thereby evading neutrophil clearance. In this way, periodontal pathogens can penetrate the epithelial barrier of periodontal tissues and achieve systemic spread through the bloodstream [31]. By this dynamic mechanism, periodontal pathogens can infect the vascular epithelium and atherosclerotic plaques, causing inflammation and plaque instability followed by acute myocardial ischemia. Moreover, periodontal pathogens produce a variety of virulence factors (e.g., adhesions, hemolysins, membrane vesicles and LPS) that have deleterious effects on the vascular system, resulting in platelet aggregation and adhesion and formation of lipidladen foam cells and deposits of cholesterol that contribute to the formation of atheromas $[32,33]$.

Buerger disease, which causes peripheral arterial disease, may have different underlying mechanisms than atherosclerosis. The pathogens involved in Buerger disease are periodontal bacteria such as $P$. gingivalis and T.denticola [34]. P. gingivalis may be an initiator of platelet aggregation, and a clump of the bacteria can enter the bloodstream from the venous angle of the neck and stimulate platelet aggregation after uptake into platelets [35]. It has been suggested that once aggregation has reached a maximum level, when the platelet thrombi pass through the lungs, the thrombi start to move into the arterial bloodstream. When patients are young and the arterial walls are spastic from cigarette smoking, platelet thrombi containing oral bacteria do not adhere to the arterial wall but rather create small arterial embolisms. It has been reported that the digital arterial obstruction observed on angiography of patients with Buerger disease may represent these initial findings [26]. The characteristics of the association between periodontitis and arterial diseases are dependent on the patient's age and the condition of the endothelial cells. In young patients with Buerger disease, infection occurs as a result of embolic mechanisms as a direct cause. In older patients, incidents result in adhesion of the endothelium and stimulation of inflammatory mediators as an indirect cause [26].

\section{Transtracheal spread of periodontal pathogens and direct effects to target organs}

Respiratory infections such as pneumonia and certain chronic obstructive diseases are related to aspiration of bacteria from the oropharynx into the lower respiratory tract due to swallowing insufficiency. Dental plaque may represent a source of potential respiratory pathogens, particularly in high-risk patients (nursing home residents, older patients, intensive care unit patients and hospitalized individuals requiring mechanical ventilation). Current evidence suggests that oral bacteria, poor oral hygiene and periodontitis may influence the initiation and course of pulmonary infections, including community-acquired, hospital-acquired and ventilatoracquired pneumonia $[36,37]$. The oral cavity is contiguous with the trachea and may be a portal for respiratory pathogen colonization. Dental plaque can be colonized by respiratory pathogens [38], which may be aspirated from the oropharynx into the upper airway and then into the lower airway and adhere to the bronchial or alveolar epithelium [39].

Potential respiratory pathogens include Klebsiella pneumonia, Escherichia coli, Pseudomonas aeruginosa, Staphylococcus aureus, Haemophilus influenzae and parainfluenzae, Streptococcus constellatus and pneumonia and oral bacteria such as $A$. actinomycetemcomitans, Actinomyces israelii, Capnocytophaga spp., Eikenella corrodens and P. intermedia. These pathogens may be aspirated into the lower respiratory tract and lungs and cause infection [40]. Cytokines and enzymes released from periodontal tissues may alter the respiratory epithelium and promote infection by potential respiratory pathogens. Moreover, enzymes derived from bacteria in saliva may damage the surface of the oral mucosa and expose receptors that promote adhesion and colonization of potential respiratory pathogens. Finally, enzymes associated with chronic periodontitis may degrade the film of saliva, decreasing the protection of nonspecific host defense mechanisms against potential respiratory pathogens [41].

The oral cavity serves as a reservoir for respiratory pathogens. Therefore, oral hygiene interventions may reduce colonization by these pathogens and consequently decrease the risk of pneumonia, especially in high-risk populations. Scannapieco and colleagues [42] conducted a systematic review of the effectiveness of oral decontamination to prevent pneumonia. A meta-analysis of five interventional studies revealed that oral interventions improving oral hygiene through mechanical and/ or chemical disinfection reduce the incidence of nosocomial pneumonia by an average of $40 \%$. A recent multicenter trial assessed the efficacy of $0.2 \%$ chlorohexidine gel in reducing the rate of pneumonia in 228 nonedentulous patients requiring endotracheal intubation and mechanical ventilation [43]. Although the intervention significantly decreased the rate of oropharyngeal colonization by aerobic pathogens, no significant reductions in the incidence of respiratory infections were observed.

\section{Oral-hematogenous spread of cytokines and antibodies with effects at distant organs}

Periodontal pathogens may gain access to the gingiva through the epithelium in periodontal pockets. Within inflamed gingival tissue, a number of inflammatory mediators, including TNF-a, IL-1 $\beta, \mathrm{PGE}_{2}$ and $\gamma$-IFN, are produced. These mediators can enter the bloodstream and contribute to systemic inflammation in conditions such as preterm delivery of low-birth-weight fetuses, 
Igari et al. Oral Biology and Dentistry 2014,

http://www.hoajonline.com/journals/pdf/2053-5775-2-4.pdf

doi: $10.7243 / 2053-5775-2-4$

osteoporosis, diabetes mellitus, renal failure and obesity.

\section{Preterm delivery of low-birth-weight fetuses}

Low-birth-weight $(<2,500 \mathrm{~g})$ and preterm (before 37 weeks of gestation) births are major determinants of neonatal infant morbidity and mortality and exert a tremendous financial impact on the public health system [44]. The first study to report the effects of poor oral health on the birth of low-birthweight and preterm infants was conducted by Offenbacher and colleagues [45]. They obtained obstetric and demographic information from the patients' prenatal records and performed full mouth periodontal examinations in 93 mothers who gave birth to preterm or low-birth-weight infants and compared the findings to those of 31 mothers who gave birth to normal weight and term infants. A multivariate analysis showed that the mothers with more than $60 \%$ of sites of clinical attachment loss of $3 \mathrm{~mm}$ or greater were seven times more likely to have an adverse pregnancy outcome than the periodontally healthy mothers ( $\mathrm{OR}=7.5 ; \mathrm{Cl} 1.98-28.8)$. Hasegawa and colleagues reported that threatened premature labor women revealed worsened periodontal health conditions and elevated levels of serum IL- 8 and IL-1 $\beta$ levels than non threatened premature labor women [46].

Periodontal pathogens, including $P$. gingivalis, have been detected using a PCR assay in the amniotic fluid of pregnant females with a diagnosis of threatened premature labor [47] as well as in the placentas of females with preeclampsia [48]. In an immunocytochemistry examination, localization of $P$. gingivalis was demonstrated in placental tissues, including syncytiotrophoblasts, chorionic trophoblasts, decidual cells, amniotic epithelial cells and vascular cells obtained from females with chorioamnionitis at fewer than 37 weeks of gestation [49]. P. gingivalis organisms were continuously infected via capillary vessels in the dorsolumbar region of a rabbit, after which $P$. gingivalis was found to achieve transplacental passage [50]. P. gingivalis has also been reported to invade both maternal and fetal tissues in rats, resulting in chorioamnionitis and placentitis [51].

The etiology of preterm birth is multifactorial; however, inflammation is the common pathway that leads to uterine contractions and cervical changes with or without premature rupture of membranes [52]. Inflammation associated with preterm birth can be primarily attributed to intrauterine infections and bacterial vaginosis. The latter accounts for up to $40 \%$ of cases of spontaneous preterm birth [53]. Affected mothers have significantly higher levels of proinflammatory cytokines and prostaglandins in their amniotic fluid. This is a common finding in females with bacterial vaginosis who deliver preterm [54]. At the same time, infections remote from the genital tract can also trigger preterm birth, as is the case for pregnant females with periodontal diseases. The biological plausibility of the link between periodontal diseases and preterm birth can be summarized based on three potential pathways [55]. The first potential pathway involves the hematogenous dissemination of inflammatory products from a periodontal infection. The second pathway involves a fetomaternal immune response to oral pathogens. The third pathway proposed to explain the theoretical causal relationship between periodontal disease and preterm birth involves bacteremia from oral infections.

\section{Diabetes mellitus}

Diabetes mellitus (DM) is a condition in which the body does not produce enough or does not properly respond to insulin, a hormone produced in the pancreas. Insulin enables cells to absorb glucose in order to turn it into energy. In diabetes mellitus, the body fails to properly respond to its own insulin or does not make enough insulin. Some patients exhibit both failures.

DM can lead to various complications such as acute/chronic infections, vascular diseases, neuropathy, nephropathy and retinopathy $[17,37]$. Chronic periodontal disease and DM are common chronic conditions in adults throughout the world [56]. A number of studies have demonstrated that poor blood sugar control may contribute to poor periodontal health [57-59] and vice versa [60]. Diabetes is a risk factor for gingivitis and periodontitis $[\mathbf{6 1}, \mathbf{6 2}]$. Patients with DM have a 2.8 -fold greater chance of developing destructive periodontal disease [63] as well as a 4.2-fold greater chance of experiencing progressive alveolar bone loss [64]. Individuals with poor blood sugar control exhibit a greater prevalence and severity of gingival and periodontal inflammation [65]. The increased risk of developing periodontal disease cannot be explained by age, gender or hygiene [66]. The interrelationship between periodontal disease and DM provides an example of a systemic disease predisposing individuals to oral infection. Once the infection is installed, it exacerbates the systemic disease [56]. It has been suggested that hyperglycemia promotes the development and progression of periodontitis $[\mathbf{6 7 , 6 8 ]}$. The complications of diabetes are related to long-term elevation of the blood glucose concentrations (hyperglycemia) that results in the formation of advanced glycation end-products (AGEs). The accumulation of AGEs increases the intensity of the immune-inflammatory response to different pathogens because inflammatory cells such as monocytes and macrophages have receptors for AGEs with consequent increased production of IL-1 $\beta$ and TNF- $\alpha$ [69]. AGE-enriched gingival tissue exhibits greater vascular permeability, greater breakdown of collagen fibers and accelerated destruction of both non-mineralized connective tissue and bone. Diabetes can also cause damage involving neutrophil adhesion, chemotaxis and phagocytosis, making patients more susceptible to periodontal destruction. The effects of a hyperglycemic state include the inhibition of osteoblastic proliferation and collagen production. Several studies have indicated that diabetes is associated with an increased prevalence, extent and severity of chronic periodontitis [37]. For this reason, chronic periodontitis has been defined as the sixth complication of diabetes; thus, 
prevention and control of chronic periodontitis must be considered an integral part of diabetes control strategies $[\mathbf{7 0 , 7 1 ]}$. Moreover, chronic periodontitis may have a significant impact on the metabolic state of diabetes. Several studies have suggested that patients with periodontitis have higher concentrations of inflammatory serum markers such as CRP, IL- 6 and fibrinogen than patients without periodontitis. Once chronic periodontitis has been established, metabolic control (glycemic control or maintenance of the blood sugar levels) may be complicated by a constant reservoir of Gram-negative anaerobes located in the bottom of periodontal pockets, thus leading to increased periodontal destruction. Systemic inflammation, in fact, increases insulin resistance and makes it difficult for patients to control their blood glucose levels [72]. It is important to monitor the hemoglobin $\mathrm{A} 1 \mathrm{c}(\mathrm{HbA} 1 \mathrm{c})$ levels to assess diabetic management, as poor glycemic control over time has been linked to the development and progression of microvascular diabetic complications [73]. Interestingly, $P$. gingivalis is detected more frequently in subjects with increased $\mathrm{HbA} 1 \mathrm{c}$ levels after periodontal treatment than in those decreased $\mathrm{HbA} 1 \mathrm{c}$ levels. Furthermore, $P$. gingivalis organisms with type II fimbriae are detected only in subjects with elevated $\mathrm{HbA} 1 \mathrm{c}$ levels, while improvements in the $\mathrm{HbA} 1 \mathrm{c}$ levels are observed only in subjects without type II clones. These results suggest that the glycemic levels in patients with DM are affected by the persistence of $P$. gingivalis in periodontal pockets, especially clones with type II fimbriae [74]. The serum AGEs are also shown to be significantly associated with deterioration caused by periodontitis [75] and may be a useful biomarker in assessing periodontitis associated with DM.

\section{Conclusion}

The current evidence suggests that inflammation caused by periodontal infections affects not only the immediate oral environment, but also the systemic organs. Periodontitislinked systemic diseases are caused by underlying mechanisms associated with $P$. gingivalis and many other bacteria. This article reviewed the literature evaluating both the historical concept of the focal infection theory and current viewpoints. There might be some evidence of epidemiological associations between periodontitis and several systemic diseases, as discussed above; hence, controlling oral diseases is essential for preventing and managing these systemic conditions. In terms of medical economics, understanding the relationship between periodontitis and systemic diseases has the potential to change health policy, ensuring economic benefits. Furthermore, the medical community should be aware of the potential negative effects of periodontal infections on systemic health. Periodontal medicine promotes strong collaboration between dental and medical professionals, which implies better communication and an effective team approach in clinical practice. Moreover, periodontal patients should be referred to medical specialists, which might improve not only systemic diseases but also the oral environment, including periodontitis.

\section{Competing interests}

The authors declare that they have no competing interests.

Authors' contributions

\begin{tabular}{|l|c|c|c|c|c|}
\hline Authors' contributions & KI & TK & TT & YI & TI \\
\hline Research concept and design & $\checkmark$ & -- & -- & -- & $\checkmark$ \\
\hline Collection and/or assembly of data & $\checkmark$ & $\checkmark$ & $\checkmark$ & -- & $\checkmark$ \\
\hline Data analysis and interpretation & $\checkmark$ & -- & -- & $\checkmark$ & -- \\
\hline Writing the article & $\checkmark$ & -- & -- & $\checkmark$ & -- \\
\hline Critical revision of the article & $\checkmark$ & -- & -- & $\checkmark$ & $\checkmark$ \\
\hline Final approval of article & $\checkmark$ & -- & -- & -- & $\checkmark$ \\
\hline Statistical analysis & $\checkmark$ & -- & -- & -- & -- \\
\hline
\end{tabular}

\section{Publication history}

Editor: William Papaioannou, University of Athens Dental School, Greece.

EIC: Thimios A. Mitsiadis, University of Zurich, Switzerland. Received: 31-Jan-2014 Final Revised: 28-Feb-2014

Accepted: 10-Apr-2014 Published: 19-Apr-2014

\section{References}

1. Miller W. The human mouth as a focus of infection. Dental Cosmos. 1891; 33:689-713. | Article

2. Offenbacher S. Periodontal diseases: pathogenesis. Ann Periodontol. 1996; 1:821-78. | Article | PubMed

3. Scannapieco FA. Position paper of The American Academy of Periodontology: periodontal disease as a potential risk factor for systemic diseases. J Periodontol. 1998; 69:841-50. | PubMed

4. Seymour GJ, Ford PJ, Cullinan MP, Leishman S and Yamazaki K. Relationship between periodontal infections and systemic disease. Clin Microbiol Infect. 2007; 13 Suppl 4:3-10. | Article I PubMed

5. Armitage GC. Development of a classification system for periodontal diseases and conditions. Ann Periodontol. 1999; 4:1-6. | Article | PubMed

6. Pizzo G, Guiglia R, Lo Russo L and Campisi G. Dentistry and internal medicine: from the focal infection theory to the periodontal medicine concept. Eur J Intern Med. 2010; 21:496-502. I Article I PubMed

7. Pihlstrom BL, Michalowicz BS and Johnson NW. Periodontal diseases. Lancet. 2005; 366:1809-20. | Article | PubMed

8. Socransky SS and Haffajee AD. Periodontal microbial ecology. Periodontol 2000. 2005; 38:135-87. | Article I PubMed

9. Milward MR, Chapple IL, Wright HJ, Millard JL, Mattews JB and Cooper PR. Differential activation of NF- $\mathrm{k} \beta$ and gene expression in oral epithelial cells by periodontal pathogens. Clin Exp Immunol. 2007; 148:307-324. | Article

10. Loos BG. Systemic markers of inflammation in periodontitis. J Periodontol. 2005; 76:2106-15. | Article | PubMed

11. Iwai T, Inoue $Y$, Umeda M, Huang $Y$, Kurihara N, Koike M and Ishikawa I. Oral bacteria in the occluded arteries of patients with Buerger disease. J Vasc Surg. 2005; 42:107-15. I Article I PubMed

12. Ishihara K, Nabuchi A, Ito R, Miyachi K, Kuramitsu HK and Okuda K. Correlation between detection rates of periodontopathic bacterial DNA in coronary stenotic artery plaque [corrected] and in dental plaque samples. J Clin Microbiol. 2004; 42:1313-5. I Article I PubMed Abstract I PubMed Full Text

13. Nakano K, Nemoto H, Nomura R, Inaba H, Yoshioka H, Taniguchi $K$, Amano $\mathrm{A}$ and Ooshima T. Detection of oral bacteria in cardiovascular 
Igari et al. Oral Biology and Dentistry 2014,

specimens. Oral Microbiol Immunol. 2009; 24:64-8. | Article | PubMed

14. Azarpazhooh A and Leake JL. Systematic review of the association between respiratory diseases and oral health. J Periodontol. 2006; 77:1465-82. | Article | PubMed

15. Leitich H, Bodner-Adler B, Brunbauer M, Kaider A, Egarter C and Husslein P. Bacterial vaginosis as a risk factor for preterm delivery: a metaanalysis. Am J Obstet Gynecol. 2003; 189:139-47. | Article I PubMed

16. Pretorius $C$, Jagatt $A$ and Lamont RF. The relationship between periodontal disease, bacterial vaginosis, and preterm birth. J Perinat Med. 2007; 35:93-9. | Article | PubMed

17. Wild S, Roglic G, Green A, Sicree R and King H. Global prevalence of diabetes: estimates for the year $\mathbf{2 0 0 0}$ and projections for 2030. Diabetes Care. 2004; 27:1047-53. | Article | PubMed

18. Janket SJ, Wightman A, Baird AE, Van Dyke TE and Jones JA. Does periodontal treatment improve glycemic control in diabetic patients? A meta-analysis of intervention studies. J Dent Res. 2005; 84:1154-9. I Article | PubMed Abstract | PubMed Full Text

19. Chen YW, Umeda M, Nagasawa T, Takeuchi Y, Huang Y, Inoue Y, Iwai T, Izumi $Y$ and Ishikawa I. Periodontitis may increase the risk of peripheral arterial disease. Eur J Vasc Endovasc Surg. 2008; 35:153-8. | Article | PubMed

20. Chen YW, Nagasawa T, Wara-Aswapati N, Ushida Y, Wang D, Takeuchi Y, Kobayashi H, Umeda M, Inoue Y, Iwai T, Ishikawa I and Izumi Y. Association between periodontitis and anti-cardiolipin antibodies in Buerger disease. J Clin Periodontol. 2009; 36:830-5. I Article I PubMed

21. Seymour GJ, Ford PJ, Cullinan MP, Leishman S, West MJ and Yamazaki $\mathrm{K}$. Infection or inflammation: the link between periodontal and cardiovascular diseases. Future Cardiol. 2009; 5:5-9. I Pdf

22. Rosamond W, Flegal K, Friday G, Furie K, Go A, Greenlund K, Haase N, Ho M, Howard V and Kissela B. Heart disease and stroke statistics--2007 update: a report from the American Heart Association Statistics Committee and Stroke Statistics Subcommittee. Circulation. 2007; 115:e69-171. | Article | PubMed

23. Hujoel PP, Drangsholt M, Spiekerman C and Derouen TA. Examining the link between coronary heart disease and the elimination of chronic dental infections. J Am Dent Assoc. 2001; 132:883-9. | Article I PubMed

24. Janket SJ, Baird AE, Chuang SK and Jones JA. Meta-analysis of periodontal disease and risk of coronary heart disease and stroke. Oral Surg Oral Med Oral Pathol Oral Radiol Endod. 2003; 95:559-69. | Article | PubMed

25. Kurihara N, Inoue Y, Iwai T, Umeda M, Huang Y and Ishikawa I. Detection and localization of periodontopathic bacteria in abdominal aortic aneurysms. Eur J Vasc Endovasc Surg. 2004; 28:553-8. | Article | PubMed

26. Iwai T. Periodontal bacteremia and various vascular diseases. J Periodontal Res. 2009; 44:689-94. | Article | PubMed

27. Ashimoto A, Chen C, Bakker I and Slots J. Polymerase chain reaction detection of 8 putative periodontal pathogens in subgingival plaque of gingivitis and advanced periodontitis lesions. Oral Microbiol Immunol. 1996; 11:266-73. | Article | PubMed

28. Toyofuku T, Inoue Y, Kurihara N, Kudo T, Jibiki M, Sugano N, Umeda M and Izumi Y. Differential detection rate of periodontopathic bacteria in atherosclerosis. Surg Today. 2011; 41:1395-400. | Article | PubMed

29. Haraszthy VI, Zambon JJ, Trevisan M, Zeid M and Genco RJ. Identification of periodontal pathogens in atheromatous plaques. J Periodontol. 2000; 71:1554-60. | Article | PubMed

30. Paraskevas S, Huizinga JD and Loos BG. A systematic review and meta-analyses on C-reactive protein in relation to periodontitis. J Clin Periodontol. 2008; 35:277-90. | Article | PubMed

31. Tonetti MS and Van Dyke TE. Periodontitis and atherosclerotic cardiovascular disease: consensus report of the Joint EFP/AAP Workshop on Periodontitis and Systemic Diseases. J Periodontol. 2013; 84:S24-9. | Article | PubMed

32. Friedewald VE, Kornman KS, Beck JD, Genco R, Goldfine A, Libby P, Offenbacher S, Ridker PM, Van Dyke TE and Roberts WC. The American Journal of Cardiology and Journal of Periodontology Editors' Consensus: periodontitis and atherosclerotic cardiovascular disease. Am J Cardiol.
2009; 104:59-68. | Article | PubMed

33. Humphrey LL, Fu R, Buckley DI, Freeman M and Helfand M. Periodontal disease and coronary heart disease incidence: a systematic review and meta-analysis. J Gen Intern Med. 2008; 23:2079-86. | Article I PubMed Abstract | PubMed Full Text

34. Chen YW, Iwai T, Umeda M, Nagasawa T, Huang Y, Takeuchi Y and Ishikawa I. Elevated IgG titers to periodontal pathogens related to Buerger disease. Int J Cardiol. 2007; 122:79-81. | Article I PubMed

35. Li X, Iwai T, Nakamura H, Inoue Y, Chen Y, Umeda M and Suzuki H. An ultrastructural study of Porphyromonas gingivalis-induced platelet aggregation. Thromb Res. 2008; 122:810-9. | Article | PubMed

36. Paju S and Scannapieco FA. Oral biofilms, periodontitis, and pulmonary infections. Oral Dis. 2007; 13:508-12. | Article | PubMed Abstract | PubMed Full Text

37. Linden GJ, Lyons A and Scannapieco FA. Periodontal systemic associations: review of the evidence. J Periodontol. 2013; 84:S8-S19. | Article | PubMed

38. Didilescu AC, Skaug N, Marica C and Didilescu C. Respiratory pathogens in dental plaque of hospitalized patients with chronic lung diseases. Clin Oral Investig. 2005; 9:141-7. I Article I PubMed

39. Scannapieco FA. Role of oral bacteria in respiratory infection. J Periodontol. 1999; 70:793-802. | Article | PubMed

40. Scannapieco FA. Pneumonia in nonambulatory patients. The role of oral bacteria and oral hygiene. J Am Dent Assoc. 2006; 137 Suppl:21S-25S. Article | PubMed

41. Bansal $M$, Khatri $M$ and Taneja V. Potential role of periodontal infection in respiratory diseases - a review. J Med Life. 2013; 6:244-8. | PubMed Abstract | PubMed Full Text

42. Scannapieco FA, Bush RB and Paju S. Associations between periodontal disease and risk for nosocomial bacterial pneumonia and chronic obstructive pulmonary disease. A systematic review. Ann Periodontol. 2003; 8:54-69. | Article | PubMed

43. Fourrier F, Dubois D, Pronnier P, Herbecq P, Leroy O, Desmettre T, PottierCau E, Boutigny H, Di Pompeo C, Durocher A and Roussel-Delvallez M. Effect of gingival and dental plaque antiseptic decontamination on nosocomial infections acquired in the intensive care unit: a doubleblind placebo-controlled multicenter study. Crit Care Med. 2005; 33:1728-35. | Article | PubMed

44. Pizzo G, La Cara M, Conti Nibali M and Guiglia R. Periodontitis and preterm delivery. A review of the literature. Minerva Stomatol. 2005; 54:1-14. | PubMed

45. Offenbacher S, Katz V, Fertik G, Collins J, Boyd D, Maynor G, McKaig R and Beck J. Periodontal infection as a possible risk factor for preterm low birth weight. J Periodontol. 1996; 67:1103-13. | Article | PubMed

46. Hasegawa K, Furuichi Y, Shimotsu A, Nakamura M, Yoshinaga M, Kamitomo M, Hatae M, Maruyama I and Izumi Y. Associations between systemic status, periodontal status, serum cytokine levels, and delivery outcomes in pregnant women with a diagnosis of threatened premature labor. J Periodontol. 2003; 74:1764-70. | $\underline{\text { Article | PubMed }}$

47. Leon R, Silva N, Ovalle A, Chaparro A, Ahumada A, Gajardo M, Martinez $M$ and Gamonal J. Detection of Porphyromonas gingivalis in the amniotic fluid in pregnant women with a diagnosis of threatened premature labor. J Periodontol. 2007; 78:1249-55. | Article | PubMed

48. Barak S, Oettinger-Barak O, Machtei EE, Sprecher H and Ohel G. Evidence of periopathogenic microorganisms in placentas of women with preeclampsia. J Periodontol. 2007; 78:670-6. | Article | PubMed

49. Katz J, Chegini N, Shiverick KT and Lamont RJ. Localization of P. gingivalis in preterm delivery placenta. J Dent Res. 2009; 88:575-8. | Article | PubMed Abstract | PubMed Full Text

50. Boggess KA, Madianos PN, Preisser JS, Moise KJ, Jr. and Offenbacher S. Chronic maternal and fetal Porphyromonas gingivalis exposure during pregnancy in rabbits. Am J Obstet Gynecol. 2005; 192:554-7. | Article | PubMed

51. Belanger M, Reyes L, von Deneen K, Reinhard MK, Progulske-Fox $A$ and Brown MB. Colonization of maternal and fetal tissues by Porphyromonas gingivalis is strain-dependent in a rodent animal 
Igari et al. Oral Biology and Dentistry 2014,

model. Am J Obstet Gynecol. 2008; 199:86 e1-7. | Article | PubMed

52. Ide $M$ and Papapanou PN. Epidemiology of association between maternal periodontal disease and adverse pregnancy outcomes-systematic review. J Clin Periodontol. 2013; 40 Suppl 14:S181-94. | Article | PubMed

53. Leitich $\mathrm{H}$, Bodner-Adler B, Brunbauer M, Kaider A, Egarter C and Husslein $P$. Bacterial vaginosis as a risk factor for preterm delivery: a metaanalysis. Am J Obstet Gynecol. 2003; 189:139-47. | Article | PubMed

54. Guaschino S, De Seta F, Piccoli M, Maso G and Alberico S. Aetiology of preterm labour: bacterial vaginosis. BJOG. 2006; 113 Suppl 3:46-51. | Article | PubMed

55. Goldenberg RL, Hauth JC and Andrews WW. Intrauterine infection and preterm delivery. N Engl J Med. 2000; 342:1500-7. | Article | PubMed

56. Kiran M, Arpak N, Unsal E and Erdogan MF. The effect of improved periodontal health on metabolic control in type $\mathbf{2}$ diabetes mellitus. $J$ Clin Periodontol. 2005; 32:266-72. | Article | PubMed

57. Cianciola LJ, Park BH, Bruck E, Mosovich L and Genco RJ. Prevalence of periodontal disease in insulin-dependent diabetes mellitus (juvenile diabetes). J Am Dent Assoc. 1982; 104:653-60. | Article | PubMed

58. Jones JA, Miller DR, Wehler CJ, Rich SE, Krall-Kaye EA, McCoy LC, Christiansen $\mathrm{CL}$, Rothendler JA and Garcia RI. Does periodontal care improve glycemic control? The Department of Veterans Affairs Dental Diabetes Study. J Clin Periodontol. 2007; 34:46-52. | Article | PubMed

59. Tan WC, Tay FB and Lim LP. Diabetes as a risk factor for periodontal disease: current status and future considerations. Ann Acad Med Singapore. 2006; 35:571-81. | Pdf | PubMed

60. Grossi SG and Genco RJ. Periodontal disease and diabetes mellitus: a two-way relationship. Ann Periodontol. 1998; 3:51-61. | Article | PubMed

61. Papapanou PN. Periodontal diseases: epidemiology. Ann Periodontol. 1996; 1:1-36. | Article | PubMed

62. Mealey BL. Periodontal implications: medically compromised patients. Ann Periodontol. 1996; 1:256-321. | Article | PubMed

63. Emrich LJ, Shlossman M and Genco RJ. Periodontal disease in noninsulin-dependent diabetes mellitus. J Periodontol. 1991; 62:123-31. | Article I PubMed

64. Taylor GW, Burt BA, Becker MP, Genco RJ and Shlossman M. Glycemic control and alveolar bone loss progression in type 2 diabetes. Ann Periodontol. 1998; 3:30-9. | Article | PubMed

65. Campus G, Salem A, Uzzau S, Baldoni E and Tonolo G. Diabetes and periodontal disease: a case-control study. J Periodontol. 2005; 76:41825. | Article | PubMed

66. Rodrigues DC, Taba MJ, Novaes AB, Souza SL and Grisi MF. Effect of nonsurgical periodontal therapy on glycemic control in patients with type 2 diabetes mellitus. J Periodontol. 2003; 74:1361-7. | Article | PubMed

67. Taylor GW. Bidirectional interrelationships between diabetes and periodontal diseases: an epidemiologic perspective. Ann Periodontol. 2001; 6:99-112. | Article | PubMed

68. lacopino AM. Periodontitis and diabetes interrelationships: role of inflammation. Ann Periodontol. 2001; 6:125-37. | PubMed

69. Schmidt AM, Weidman E, Lalla E, Yan SD, Hori O, Cao R, Brett JG and Lamster IB. Advanced glycation endproducts (AGEs) induce oxidant stress in the gingiva: a potential mechanism underlying accelerated periodontal disease associated with diabetes. J Periodontal Res. 1996; 31:508-15. | Article | PubMed

70. Mealey BL and Ocampo GL. Diabetes mellitus and periodontal disease. Periodontol 2000. 2007; 44:127-53. | Article | PubMed

71. Loe H. Periodontal disease. The sixth complication of diabetes mellitus. Diabetes Care. 1993; 16:329-34. | PubMed

72. D'Aiuto F, Parkar M, Andreou G, Suvan J, Brett PM, Ready D and Tonetti MS. Periodontitis and systemic inflammation: control of the local infection is associated with a reduction in serum inflammatory markers. J Dent Res. 2004; 83:156-60. | Article | PubMed

73. Tervonen T, Lamminsalo S, Hiltunen L, Raunio T and Knuuttila M. Resolution of periodontal inflammation does not guarantee improved glycemic control in type 1 diabetic subjects. J Clin Periodontol. 2009; 36:51-7. | Article | PubMed

74. Makiura N, Ojima M, Kou Y, Furuta N, Okahashi N, Shizukuishi S and Amano A. Relationship of Porphyromonas gingivalis with glycemic level in patients with type $\mathbf{2}$ diabetes following periodontal treatment. Oral Microbiol Immunol. 2008; 23:348-51. | Article | PubMed

75. Takeda M, Ojima M, Yoshioka H, Inaba H, Kogo M, Shizukuishi S, Nomura $M$ and Amano $A$. Relationship of serum advanced glycation end products with deterioration of periodontitis in type 2 diabetes patients. J Periodontol. 2006; 77:15-20. | Article | PubMed

\section{Citation:}

Igari K, Kudo T, Toyofuku T, Inoue Y and Iwai

T. Association between periodontitis and the development of systemic diseases. Oral Biol Dent. 2014; 2:4.

http://dx.doi.org/10.7243/2053-5775-2-4 